\title{
Estudio sobre los procesos de corrosión (alteración química) de los materiales pétreos de la Catedral de Sevilla (España)
}

\section{Corrosion processes (chemical deterioration) on the stones used in the Cathedral of Seville (Spain)}

\author{
M. A. BELLO Y A. MARTIN \\ Departamento de Química Analitica \\ Facultad de Química \\ Universidad de Sevilla \\ c/ Prof. Garcia Gonzalez, s/n - 41012 - Sevilla
}

Fecha de recepción: 18-X-1990

ESPAÑA

\section{RESUMEN}

Factores importantes de alteración que contribuyen de manera significativa al preocupante estado de degradación de los materiales pétreos de la Catedral de Sevilla, esencialmente los utilizados con fines ornamentales, son aquellos de naturaleza antropogénica que, a través de mecanismos de corrosión (alteración química), determinan las principales manifestaciones macroscópicas de alteración características de este edificio.

En este informe se recogen algunos resultados de una investigación realizada sobre diversos aspectos de la alteración química experimentada por los principales litotipos empleados en la construcción de la Catedral de Sevilla.

\section{SUMMARY}

Important factors of deterioration which contribute significately to the worrying state of degradation of the petreous materials in the Cathedral of Seville, essentially those used for ornamental objects, are those of anthropogenic nature which through corrosion mechanisms (chemical deterioration) determine the main macroscopical manifestations of the characteristic deterioration of this building.

In this report, some of the results of an investigation carried out on diverse aspects of chemical deterioration experienced by the main lithotypes used in the construction of the Cathedral of Sevilla are gathered.

\section{INTRODUCCION}

La piedra se ha utilizado ampliamente desde hace siglos como material básico en la construcción de obras monumentales. Las estructuras de piedra, aun siendo más "duraderas" que aquellas de otros materiales están sometidas siempre al ataque por agentes naturales, si bien los daños se producen generalmente en el transcurso de grandes espacios de tiempo. Sin embargo, las actividades humanas de la moderna sociedad industrializada han contribuido, de manera casi inadvertida, a una aceleración dramática de la degradación de estructuras pétreas pertenecientes a obras históricas hasta el punto de que en muchos casos es posible percibir claramente año a año la alteración de monumentos construidos hace centurias $\theta$ incluso milenios.

\section{INTRODUCTION}

Stone has been widely used as a basic material in the construction of monumental works for many centuries. The structures of stone, although being harder wearing than those of other materials are always open to attack by natural agents, the damage normally occurring over long periods of time. However, human activities in our modern industrialized society have contributed, without hardly being noticed, to a dramatic acceleration in the deterioration of petreous structures in historical works so much that in many cases it is possible to clearly see the yearly deterioration of monuments constructed many hundreds or even thousands of year ago. 
Tal es el caso de la Catedral de Sevilla que, ubicada en el centro urbano, está rodeada por vías de alta densidad de tráfico; los valores de $\mathrm{SO}_{2}$ y de otros contaminantes atmosféricos en los alrededores del edificio superan con creces la media anual de la Ciudad.

Las lluvias, que en Sevilla pueden ir acompañadas de vientos del SO, que provocan el azote por agua de la Catedral; el hecho de que la capa freática se encuentre a escasa profundidad, lo que se traduce en una importante ascensión capilar por las paredes del edificio; la fuerte insolación y la elevada humedad relativa en la zona, con nieblas frecuentes durante una buena parte del año, con lo que se favorecen los ciclos de cristalización y disolución de sales; son todos ellos factores de alteración naturales importantes en la Catedral de Sevilla. Con la lenta acción destructora de dichos factores colaboran, de una manera altamente eficaz, los contaminantes atmosféricos bien en forma de gases, provenientes principalmente de los combustibles usados en los motores de los vehículos que circulan y aparcan en los alrededores del monumento, o en forma de materiales pulverulentos, que los vientos predominantes arrastran hacia la Catedral procedentes de los muelles próximos.

La corrosión antropogénica, que parece ser la alteración más representativa, la de mayor signifícación, en el estado actual de deterioro de la Catedral, produce cambios sustanciales en la naturaleza macro y microquímica de los materiales pétreos y on su estructura y textura, como consecuencia de procesos químicos fruto de la contaminación ambiental.

\section{CONDICIONES AMBIENTALES}

Dada la impcrtancia que tiene el entorno en la alteración de las piedras de la Catedral de Sevilla, se considera conveniente señalar algunos datos de interés sobre las condiciones climáticas y los indices de contaminación en el ambiente más inmediato al edificio.

\subsection{Cllmatología (1-4)}

Sevilla pertenece a la región climática denominada "Continental atenuada, zona sur". La temperatura media anual es de $18^{\circ} \mathrm{C}$, y aunque las oscilaciones térmicas
Such is the case of the Cathedral of Seville which, located in the urban centre, is surrounded by roads of high traffic density; the sulphur dioxide values and other pollutants in the atmosphere in the surroundings of the building well exceed the yearly average for the city.

The rains, which can be accompanied by southwestern winds, provokes the whip by water on the Cathedral; the fact that the phreatic layer is found at low depth is rendered into an important capillary ascension in the walls of the building; the high insolation and relative humidity in the area, with frequent fogs during a good part of the year, favours the salt crystallization and dissolution cycles, etc; these are all factors of important natural deterioration in the Cathedral of Seville.

The pollutants of the atmosphere as gases, mainly coming from the combustible fuel used in the engines of the vehicles which circulate and park in the surroundings of the building, or the pulverulent materials which the prevailing winds bring from the nearby docks collaborate with the natural deterioration factors to the slow destructive action on the building.

The anthropogenic corrosion, which seems to be the most representative deterioration, of major significance in the actual state of deterioration in the Cathedral, produces substantial changes in the macro and microchemical nature of the petreous materials and in its structure and texture, as a consequence of chemical processes product of the environmental pollution.

\section{ENVIRONMENTAL CONDITIONS}

Given the importance that the environment has on the deterioration of the stones in the Cathedral of Seville, we consider it convenient to point out some data of interest on the climatic conditions and contamination indexes in the nearer surroundings of the building.

\subsection{Climatology (1-4)}

Seville belongs to the climatic region denominated "attenuated Continental, southern zone". The average annual temperature is $18^{\circ} \mathrm{C}$ and although the 
no son muy acusadas hay que destacar los altos valores de temperatura que se alcanzan durante el verano (la temperatura media de las máximas en los meses de Julio y Agosto es aproximadamente de $\left.36^{\circ} \mathrm{C}\right)$. El valor medio anual de radiación solar es de $1.73 \mathrm{MWh} / \mathrm{m}^{2}$. La humedad relativa es alta, con una media anual del $68 \%$, y un gran número de días al año con valores próximos, e incluso superiores, al $80 \%$. La precipitación media anual es de $585 \mathrm{l} / \mathrm{m}^{2}$, con un número medio de 80 días de lluvia al año. El viento predominante es del suroeste, generalmente con velocidades inferiores a los $6 \mathrm{~km} / \mathrm{h}$.

Los altos valores en la temperatura mínima y bajas velocidades de los vientos favorecen la aparición de fenómenos de inversión térmica, lo que dificulta la dispersión de los contaminantes. Los altos valores de humedad relativa y de radiación solar facilitan las reacciones químicas secundarias.

\subsection{Contaminación}

En el entorno de la Catedral se alcanzan medias diarias de $225 \mu \mathrm{g} / \mathrm{m}^{2}$ de partículas sedimentables, $64 \mu \mathrm{g} / \mathrm{m}^{3}$ de $\mathrm{SO}_{2}$ y $50 \mu \mathrm{g} / \mathrm{m}^{3}$ de humos (5-7), valores que superan la media de la ciudad y que dan idea del alto grado de contaminación a que se encuentra sometido el monumento. Las mayores concentraciones de $\mathrm{SO}_{2}$ se alcanzan en la fachada sur del edificio, debido fundamentalmente a las paradas de autobuses y al elevado número de vehículos de motor de diversa potencia que aparcan en sus proximidades; valores igualmente elevados se han encontrado en la fachada de poniente, fruto del intenso tráfico en la Avenida de la Constitución, que bordea la fachada principal del edificio.

Cabe señalar, asimismo, la elevada concentración encontrada en la fracción insoluble de la materia sedimentable de diversos elementos metálicos traza, algunos de los cuales pueden actuar como catalizadores en ciertas reacciones químicas con influencia directa sobre la alteración del edificio. El porcentaje de plomo en la materia en suspensión es del orden del $0.5 \%$.

Existe una relación muy directa entre la concentración de $\mathrm{SO}_{2}$, los niveles de inmisión de plomo y la intensidad de tráfico en el entorno de la Catedral (8). thermic oscillations are not very great we have to emphasize the high temperatures that are reached in Summer (the average maximum temperature in July and August is approximately $36^{\circ} \mathrm{C}$ ). The average annual value of solar radiation is $1.73 \mathrm{MWh} / \mathrm{m}^{2}$. The relative humidity is high, the annual average is $68 \%$, and a great number of days it has values near or even above $80 \%$. The average annual rainfall is $585 \mathrm{l} / \mathrm{m}^{2}$ with an average of 80 days of rain/year. The prevailing wind is southwestern, usually below $6 \mathrm{Km} / \mathrm{h}$.

The high minimum temperature and low wind speeds favour the appearance of termic inversion phenomena which makes the dispersion of pollutants difficult. The high relative humidity and solar radiation make secondary chemical reactions easy.

\subsection{Pollution}

In the surroundings of the Cathedral daily averages of $225 \mu \mathrm{g} / \mathrm{m}^{2}$ of sedimentable particles, $64 \mu \mathrm{g} / \mathrm{m}^{3}$ of $\mathrm{SO}_{2}$ and $50 \mu \mathrm{g} / \mathrm{m}^{3}$ of smokes are reached (5-7), values which surpass the average of the city and which point out the high grade of contamination that the building has to suffer. The greatest concentrations of $\mathrm{SO}_{2}$ are reached on the southern facade of the building due to the busstops and the high number of diverse motor vehicles which park nearby; the same values have been found on the western side, due to the intense traffic in the Avenida de la Constitución which borders the main facade of the building.

It is worth pointing out, at the same time, the high concentration found in the insoluble fraction of the sedimentable matter of diverse trace metallic elements, some of which can act as catalysts in certain chemical reactions with direct influence on the deterioration of the building. The percentage of lead in the suspended matter is around $0.5 \%$.

A direct relation between the $\mathrm{SO}_{2}$ concentration, the levels of lead inmission and the intensity of traffic around the Cathedral does exist (8). 


\section{MATERIALES EMPLEADOS}

Aunque según los Archivos Catedralícios se han empleado en la construcción de la Catedral de Sevilla piedras procedentes de más de 20 canteras diferentes, sólo se han encontrado en las zonas exteriores materiales procedentes de cinco canteras: Puerto de Santa María (Cádiz), que son, con diferencia, los más abundantes del edificio puesto que constituyen prácticamente la totalidad del material estructural y gran parte del ornamental; Espera (Cádiz), por orden de importancia los segundos del edificio, y aunque constituyen la práctica totalidad de algunas zonas del monumento, es frecuente que aparezcan mezclados con los del Puerto de Santa María en motivos ornamentales; materiales de las canteras de Monóvar (Alicante), Utrera y Morón (ambas de Sevilla), sólo se hallan representados en zonas muy concretas de la Catedral y constituyen una mínima parte del conjunto.

\subsection{Características mineralógico-petrográficas}

Puerto de Santa María. Calcarenitas esparíticas más o menos bioclásticas, de textura heterogranuda inequigranular, matriz esparítica muy escasa, con grado de cementación bajo, lo que ocasiona una porosidad intergranular muy desarrollada, con poros medianos a grandes, irregulares, interconectados o no, así como poros móldicos.

Espera. Bioesparitas de textura heterogranuda inequigranular, de matriz esparítica, ausente en algunos casos, poco cementadas, con una porosidad media a alta de tipo intergranular a favor de poros irregulares de tamaño mediano a grande, normalmente interconectados y también poros móldicos. Procesos de recristalización interna importantes, tapizando la superficio de los huecos, especialmente de los fósiles.

Monóvar. Caliza Jurásica de textura coloforme colítica, con oolitos concéntricos con contorno circular muy homogéneo, bien cementados por una matriz microcristalina y por grandes cristales de calcita, lo que le confiere una porosidad prácticamente nula.

Utrera. Bioesparitas más o menos arenosas, de textura heterogranuda inequigranular, de matriz esparística con un grado de empaquetamiento y de cementación mediano a alto. La porosidad,

\section{MATERIALS EMPLOYED}

Although, according to the Cathedral archives, stones from 20 different quarries have been employed in the construction of the Cathedral of Seville; only materials from five quarries have been found in the exterior areas: Puerto de Santa María (Cádiz), which are, by far, the most common in the building as they constitute practically all the structural material and a large part of the ornamental; Espera (Cádiz) second in importance in the building and although they constitute nearly all the stones in some areas of the building, it is frequent to see them mixed with those from Puerto de Santa Maria for ornamental purposes; materials from Monóvar (Alicante) Utrera and Morón (both in Seville) quarries are only found in very concrete parts of the Cathedral and constitute a minimum part of the Conjunt.

\subsection{Mineralogical-petrographic characteristics}

Puerto de Santa María. Sparitic calcarenites which are more or less bioclastic, heterograined ingequigranular texture, very scarce sparitic matrix with a low degree of cementation which causes a well-developed intergranular porosity, with middlingto large pores, irregular, interconnected or not, as well as mouldic pores.

Espera. Biosparites with heterograined inequigranular texture, of sparitic matrix, absent in some cases, little cemented, with a middling to high porosity of intergranular type favouring irregular pores of middling to large in size, normally interconnected and also mouldic pores. Important internal recrystallization processes, "draping" the surface of the holes, specially the fossil ones.

Monóvar. Jurassic limestone of coloform oolitic texture, with concentric colites with a very homogeneous round shape, well cemented by a microcrystalline matrix and by large crystals of calcite which bestows it with a practically null porosity.

Utrera. More or less arenose biosparites, of heterograined inequigranular texture, sparitic matrix with a degree of packeting and cementation middling to high. The porosity, which is middling to high, is more often 
que es de mediana a alta, se desarrolla más frecuentemente a favor de poros móldicos, estando también representada por tipo intergranular, mediante poros pequeños, irregulares y no siempre conectados. Hay una recristalización calcítica secundaria muy extendida.

Morón. Calcarenita microesparística recristalizada, de textura equigranuda alotriomorfa, cuya matriz, inicialmente de grano fino, ha sido posteriormente recristalizada. El grado de cementación y empaquetamiento es mediano. La porosidad es intergranular, mediana a alta, con poros pequeños-medianos irregulares $y$ frecuentemente conectados.

\subsection{Composición macroquímica}

En la Tabla I aparecen las composiciones medias de los distintos tipos de piedras empleados en los exteriores de la Catedral de Sevilla. Cabe señalar la gran variabilidad en la composición macroquímica que presentan aquellas procedentes de las canteras del Puerto de Santa María. Los valores incluidos en la tabla corresponden a muestras del sustrato no alterado de piedras del edificio. La identificación de las canteras de procedencia de los materiales pétreos del monumento fue posible mediante técnicas quimiométricas (9). developed towards mouldic pores, also being represented by the intergranular type by means of small irregular pores not always connecting. There is a widespread secondary calcitic recrystallization.

Morón. Recrystallized microsparitic calcarenite, equigrained alotriomorphic texture whose matrix, initially of fine grain, has been later recrystallized. The degree of cementation and packeting is middling. The porosity is intergranular, middling to high, with small to middle sized irregular pores which are frequently connected.

\subsection{Macrochemical composition}

In Table I the average compositions of the different types of stones used in the exteriors of the Cathedral of Seville are shown. We emphasize the great variation in the macrochemical composition

which those proceeding from the Puerto de Santa Maria quarries present. The values included in the table correspond to samples from the non-deteriorated substratum of the stones from the building. The identification of the quarries of origin of the petreous materials was possible by chemometric techniques (9).

TABLA I (TABLE I)

Composición macroquímica media de los distintos litotipos empleados en la construcción de la Catedral de Sevilla

(Types of stones used in the Cathedral of Sevilla: representative chemical analises)

\begin{tabular}{|l|ccccccccc|}
\cline { 2 - 10 } & $\begin{array}{c}\text { Pérdida por } \\
\text { calcinación } \\
\text { (Coss on ignition) }\end{array}$ & $\mathrm{SiO}_{2}$ & $\mathrm{Al}_{2} \mathrm{O}_{3}$ & $\mathrm{Fe}_{2} \mathrm{O}_{3}$ & $\mathrm{CaO}$ & $\mathrm{MgO}$ & $\mathrm{Na}_{2} \mathrm{O}$ & $\mathrm{K}_{2} \mathrm{O}$ & $\mathrm{SO}_{3}$ \\
\hline & 22.44 & 48.34 & 0.26 & 0.16 & 27.97 & 0.13 & 0.07 & 0.09 & 0.48 \\
Puerto de & 23.87 & 44.52 & 0.25 & 0.14 & 30.25 & 0.13 & 0.11 & 0.13 & 0.57 \\
Santa Marla & 25.70 & 40.40 & 0.23 & 0.15 & 32.51 & 0.12 & 0.08 & 0.09 & 0.63 \\
& 28.08 & 34.97 & 0.18 & 0.14 & 35.61 & 0.12 & 0.06 & 0.08 & 0.64 \\
\hline Espera & 31.05 & 27,85 & 0.33 & 0.20 & 39.61 & 0.17 & 0.09 & 0.09 & 0.35 \\
\hline Monóvar & 35.23 & 19.17 & 0.12 & 0.12 & 44.41 & 0.19 & 0.10 & 0.10 & 0.33 \\
\hline Utrera & 40.67 & 4.43 & 0.78 & 0.78 & 51.28 & 0.41 & 0.07 & 0.18 & 0.51 \\
\hline Morón & 43.43 & 0.06 & 0.02 & 0.02 & 55.18 & 0.25 & 0.87 & 0.23 & 0.43 \\
\hline
\end{tabular}


Como se puede observar, se trata en todos los casos de materiales eminentemente calizos, lo que justifica, como se verá más adelante, su elevada "sensibilidad" al ataque por sustancias ácidas, y más concretamente al dióxido de azuîre.

\section{ESTADO DE ALTERACION DE LOS MATERIALES PETREOS}

Aunque en la Catedral de Sevilla se presentan manifestaciones macroscópicas de alteración de muy diversa índole (10), los indicadores visuales de alteración más significativos son aquellos que corresponden a procesos de corrosión a causa de la contaminación ambiental:

- Depósitos, fundamentalmente de inquemados, que actuan como puntos preferenciales en el transcurso de las reacciones químicas por su gran capacidad de absorción y adsorción, y

- Costras, formadas mayoritariamente por sulfato cálcico, que con frecuencia poseen gran espesor y que son fruto del ataque químico del $\mathrm{SO}_{2}$; éstas al desprenderse dejan al descubierto material arenizado, más "sensible" a un posterior ataque.

Generalmente, ambos indicadores suelen aparecer íntimamente asociados.

\subsection{Composición macroquímica}

Para establecer la variación en la composición macroquímica de los citados procesos de alteración, en cada punto de muestreo se ha obtenido una muestra superficial y una profunda inalterada. En determinados casos se estudiaron muestras de profundidad intermedia entre ambas, a fin de comprobar la variación progresiva en la composición.

Como puede apreciarse en la Figura 1, al progresar la alteración va disminuyendo el valor de pérdida por calcinación, así como aumenta el porcentaje de $\mathrm{SO}_{3}$. La naturaleza del compuesto formado, sulfato cálcico, se ha puesto de manifiesto mediante estudios por difracción de rayos $X$. En la Figura 2 se observa como
As can be seen, the materials used in every case are eminently calcareous, which justifies, as can be seen later, its high "sensitiveness" to attack by acid substances and to be more exact to sulphur dioxide.

\section{DETERIORATION STATE OF THE PETREOUS MATERIALS}

\begin{abstract}
Although there are macroscopical manifestations of very different natures in the Cathedral of Seville (10), the visual indicators of the more significant deteriorations are those which correspond to corrosion processes due to environmental pollution.
\end{abstract}

- Deposits, basically non-burnt, that act as preferential points in the chemical reactions for their great capacity of absorption and adsorption.

- Crusts, mainly formed by calcium sulphate which frequently possess great thickness and are a result of chemical attack by $\mathrm{SO}_{2}$; when these fall off leave the arenose material open to a further attack.

Generally both indicators seem to be intimately associated.

\subsection{Macrochemical composition}

To establish the variation in the macrochemical composition of the cited processes of deterioration we have taken a superficial sample and one depth unchanged from each sampling point; in certain cases, samples taken from a depth between the other two were studied with the aim of checking the progressive variation in the composition.

As can be seen in Figure 1 as the deterioration progresses, the loss of ignition decreases and the percentage of $\mathrm{SO}_{3}$ increases. The nature of the compund formed, calcium sulphate, has been shown by $X$-ray diffraction. In figure 2 we can see how the deterioration produces a decrease in the quantity of the original calcite and 
la alteración produce una disminución en la cantidad de la calcita original y la aparición de yeso. El grado de conversión llega a ser en algunas muestras estudiadas tan elevado, que se aproxima al $80 \%$.

El parámetro $\mathrm{SiO}_{2} / \mathrm{R}_{2} \mathrm{O}_{3}$ (porcentaje de sílice/suma de los porcentajes de óxido de hierro y aluminio) es un índice del grado de alteración en materiales pétreos con porcentajes de $\mathrm{SiO}_{2}$ medios y elevados $(11-14)$. En las muestras estudiadas se observa, en general, una disminución de dicho parámetro a medida que se avanza hacia el exterior de la piedra; este descenso progresivo entre el corazón inalterado y la superficie oscila entre un 7 y un $93 \%$, y guarda generalmente relación directa con el porcentaje de sulfatos en la piedra. the apparition of gypsum. The degree of conversion becomes so high in some sample that it approaches $80 \%$.

The $\mathrm{SiO}_{2} / \mathrm{R}_{2} \mathrm{O}_{3}$ parametre (percentage of quartz/sum of the percentages of iron and aluminium oxides) is an indicator of the deterioration degree in petreous materials with high and midling percentages of $\mathrm{SiO}_{2}$ (11-14). In the samples studied we observe, in general, a decrease in the parametre as it advances towards the exterior of the stone; this progressive decrease between the non-deteriorated core and the surface oscillates between 7 and $93 \%$ and has a direct relationship with the percentage of sulphates in the stone.

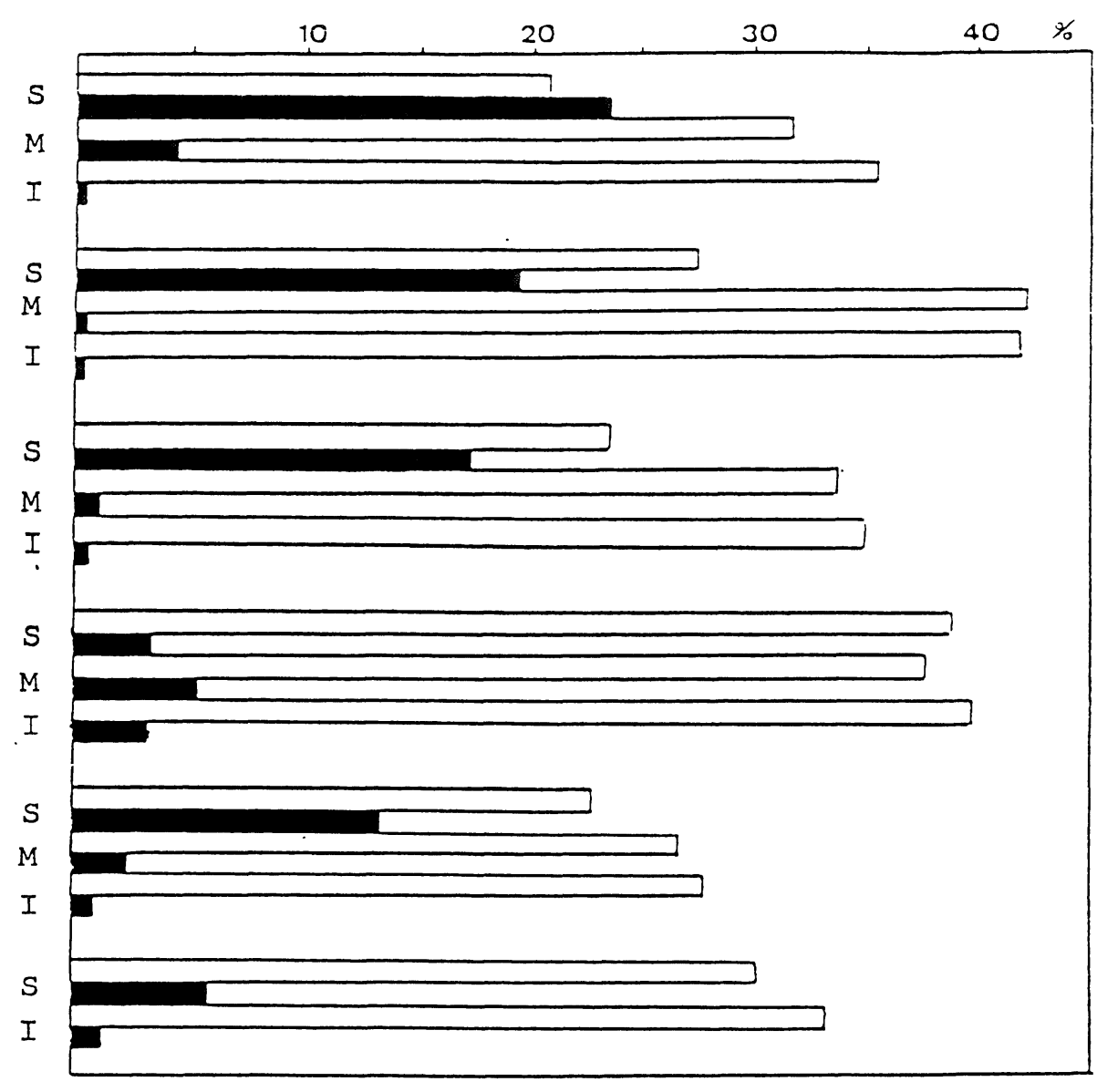

CLAVE: $\square$ Pérdida; $\mathrm{SO}_{3}$ (CODE: $\square$ Loss on ignition; $\square \mathrm{SO}_{3}$

Fig. 1.-Variación de los porcentajes de pérdida por calcinación y $\mathrm{SO}_{3}$ con la profundidad para varias muestras de la Catedral.

Fig. 1.- Variation on percentages of loss on ignition and $\mathrm{SO}_{3}$ with the depth for various Cathedral samples. 

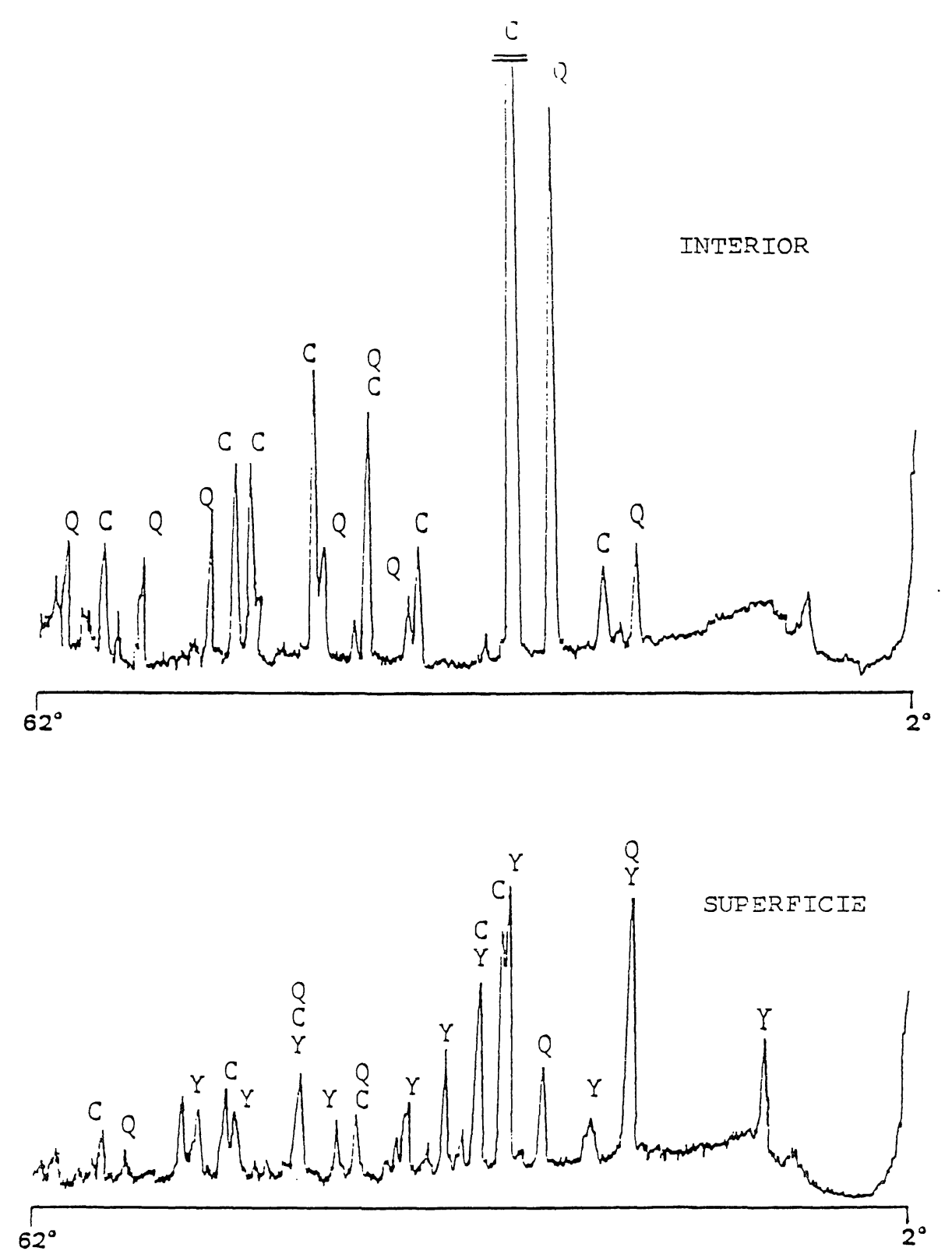

CLAVE: C calcita; $Q$ cuarzo; $Y$ yeso (CODE: C calcite; $Q$ quartz; $Y$ gypsum).

Fig. 2.-Difractogramas de rayos $X$ de una muestra alterada y de su correspondiente muestra profunda inalterada.

Fig. 2.-X-ray diffraction diagrams for deteriorated stone and corresponding unaltered sample.

\subsection{Composición microquímica}

El establecimiento de la variación de la composición microquímica como consecuencia de los procesos de corrosión permite relacionar los factores de enriquecimiento de los microcomponentes con los factores de alteración.

Diversas acciones antropogénicas externas han condicionado el grado de

\subsection{Microchemical composition}

The establishing of the variation of the microchemical composition as a consequence of the processes of corrosion permits us to connect the factors of enrichment of the microcomponents with the deterioration factors.

Diverse external anthropogenic actions have conditioned the degree of enrichment of 


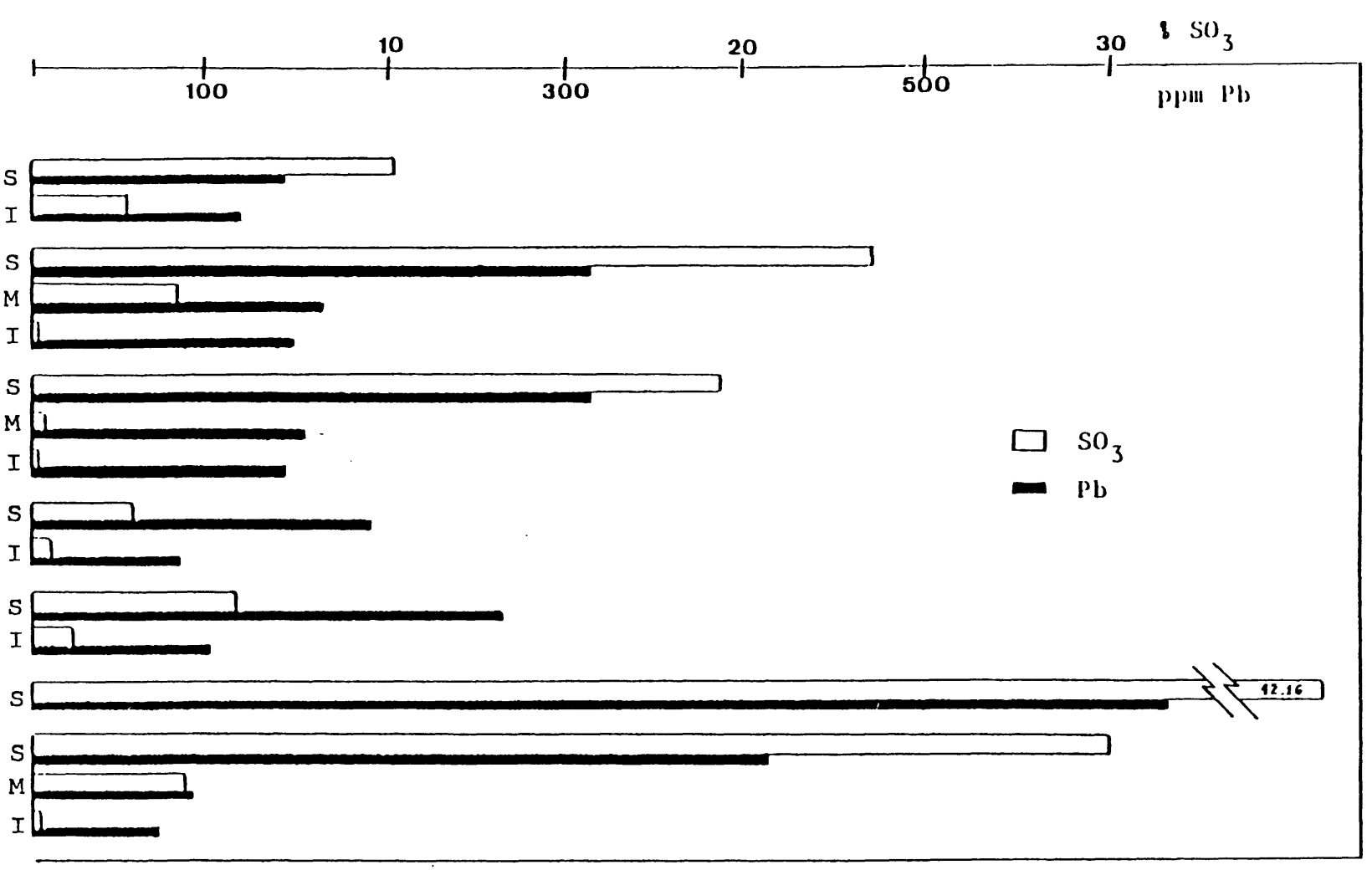

Fig. 3.-Contenidos de sulfato y plomo para varias muestras de la Catedral.

Fig. 3.-Sulphate and lead contents for various samples from the Cathedral.

enriquecimiento de dichos

microconstituyentes en la superficie de la piedra (15). Así, la incineración de residuos urbanos parece ser la principal fuente de aporte de zinc y cadmio al medio ambiente; la combustión de fuel en calefacciones y motores diesel, las de vanadio y níquel; la combustión de gasolinas la de plomo; no tienen origen tan claro las de aluminio, hierro, cobalto, titanio, cromo y manganeso, aunque posiblemente, sus fuentes principales sean la erosión del suelo y esencialmente las partículas que, arrastradas por los vientos del suroeste, provienen de las faenas de carga y descarga en la zona portuaria de Sevilla, próxima al centro de la ciudad.

En la Figura 3 se representan los contenidos de sulfato y plomo para varias muestras de la Catedral; se observa como el contenido de plomo disminuye hacia el interior de la piedra, lo que indica su aporte externo. Por otra parte, la relación existente entre el porcentaje de sulfatos en la piedra y el contenido en plomo de la misma, hace pensar que la principal fuente de dióxido de azufre en los alrededores del edificio es la circulación de automóviles. various microcomponents on the surface of the stone (15). So, the incineration of urban redidues seem to be main source of contribution of zinc and cadmium to the environment; the combustion of fuel in heaters and motor engines those of vanadium and niquel; the combustion of petrol that of lead. Those of aluminium, iron, cobalt, titanium, chromium and manganese do not have such a clear origin although their main sources are possibly the ground erosion and essentially the particles, which brought by the southwestern winds, come from the task of loading and unloading in the dock area of Seville, near the city centre.

In Figure 3 the lead and sulphate, contents are represented for several samples from the Cathedral; we see how the lead content decreases towards the interior of the stone, which indicates its external contribution. On the other hand the relationship existing between the sulphate percentage in the stone and the lead content makes us believe that the main source of sulphur dioxide in the surroundings of the building is from the circulation of motor cars. 


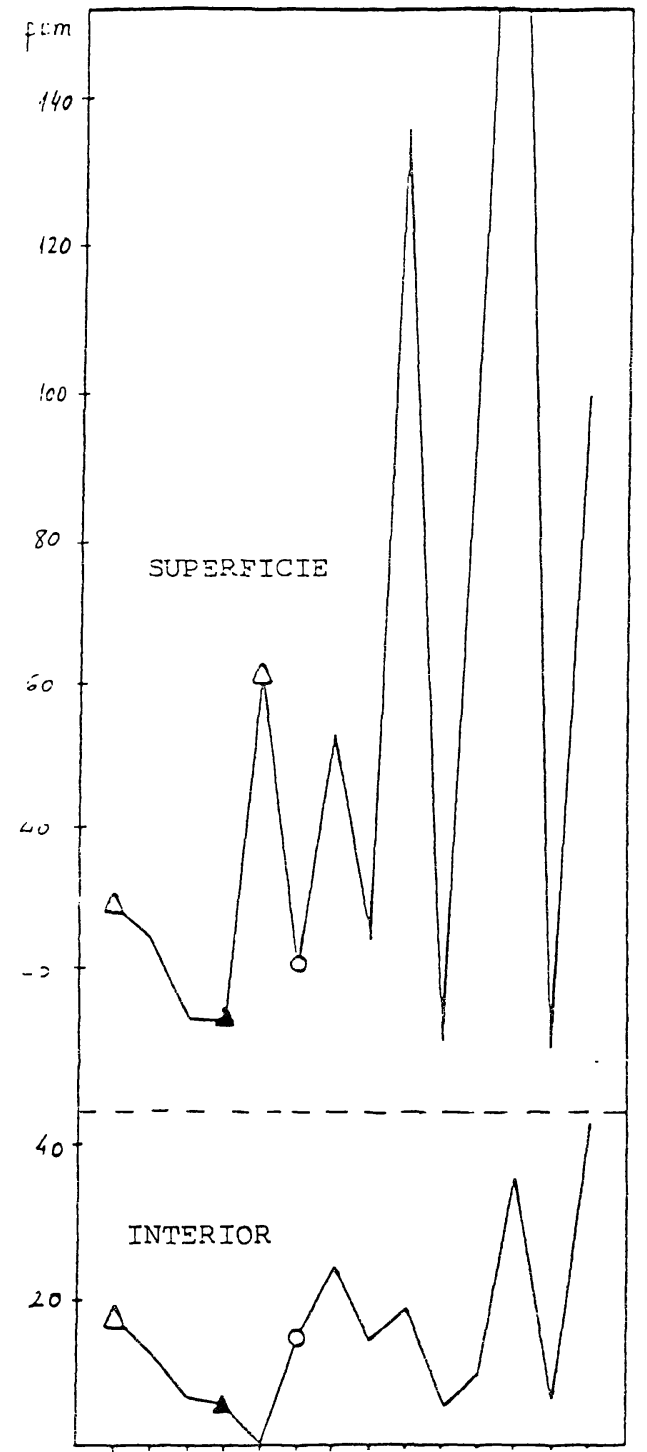

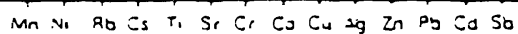

CLAVE: $\Delta 1 / 2$ de la escala; $\Delta$ 1/5 0 1/20 CODE: $\triangle 1 / 2$ of the scale; $\triangle 1 / 5$ o $1 / 20$

Fig. 4.- "Diagramas de enriquecimiento de elementos traza" de una muestra alterada.

Fig. 4.- "Trace elements enrichment diagrams" for deteriorated stone.

In the "enrichment diagrams of trace elements" in Figure 4 we can appreciate the general enrichment of all the microcomponents in the surface of the deteriorated stone.

\subsection{Soluble saits}

An assessment of the total amount of soluble salts present in the stone can be carried out by measuring the conductivity of the aqueous extract (16). In the conjuni of non-deteriorated samples the conductivity of the aqueous extract has values comprising between 37 and $69 \mu \mathrm{S} / \mathrm{cm}$. Depending the iypy of stone and the degree of deterioration, the values of conductivity are seen to be remarkably increased, oven reaching conductivities of around $800 \mu \mathrm{S} / \mathrm{cm}$. 
Los iones predominantes en la solución acuosa son calcio y sulfatos, procedentes con toda probabilidad de la solubilización del sulfato de calcio formado por acción del $\mathrm{SO}_{2}$ sobre los materiales pétreos.

En la Figura 5 se aprecia una relación directa entre el valor de conductividad del extracto acuoso y el contenido de sulfatos, tanto en dicho o extracto como en la totalidad de la piedra, de lo que se desprende, junto con los datos de análisis de la fracción acuosa, que las sales presentes en las piedras de la Catedral están constituidas casi exclusivamente por sulfato cálcico.

En la superficie de la piedra se produce, como puede apreciarse en la Figura 6, una solubilización generalizada de todos los componentes, aún sin un ataque intenso por $\mathrm{SO}_{2}$.
The predominant ions in the aqueous solution are calcium and sulphate, most likely proceeding from the solubilization of the calcium sulphate formed by the action of $\mathrm{SO}_{2}$ on the petreous materials.

In the Figure 5 a direct relationship between the value of the conductivity of the aqueous extract and the sulphur content can be seen, from which we deduce, together with the data of analysis of the aqueous fraction, that the salts present in the stone of the Cathedral are constituted almost exclusively of calcium sulphate.

A generalized solubilization of all the components on the surface of the stone, even without an intense $\mathrm{SO}_{2}$ attack, is produced, as can be seen in Figure 6.
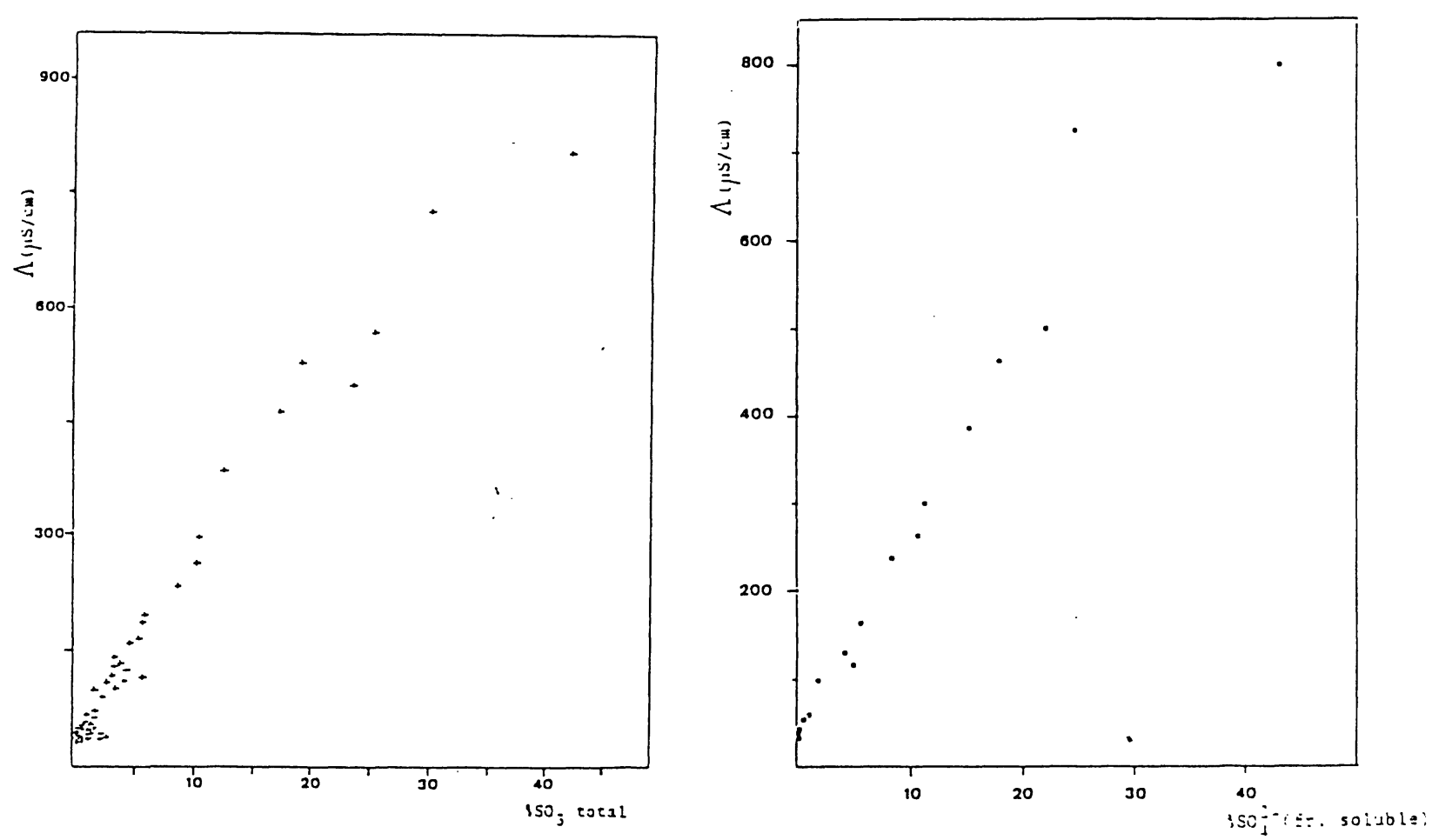

Fig. 5.-Variación de la conductividad con el porcentaje de sultatos (total y solubles en agua).

Fig. 5.-Conductivity variation of the aqueous extract with the sulphate percentages (total and water soluble). 


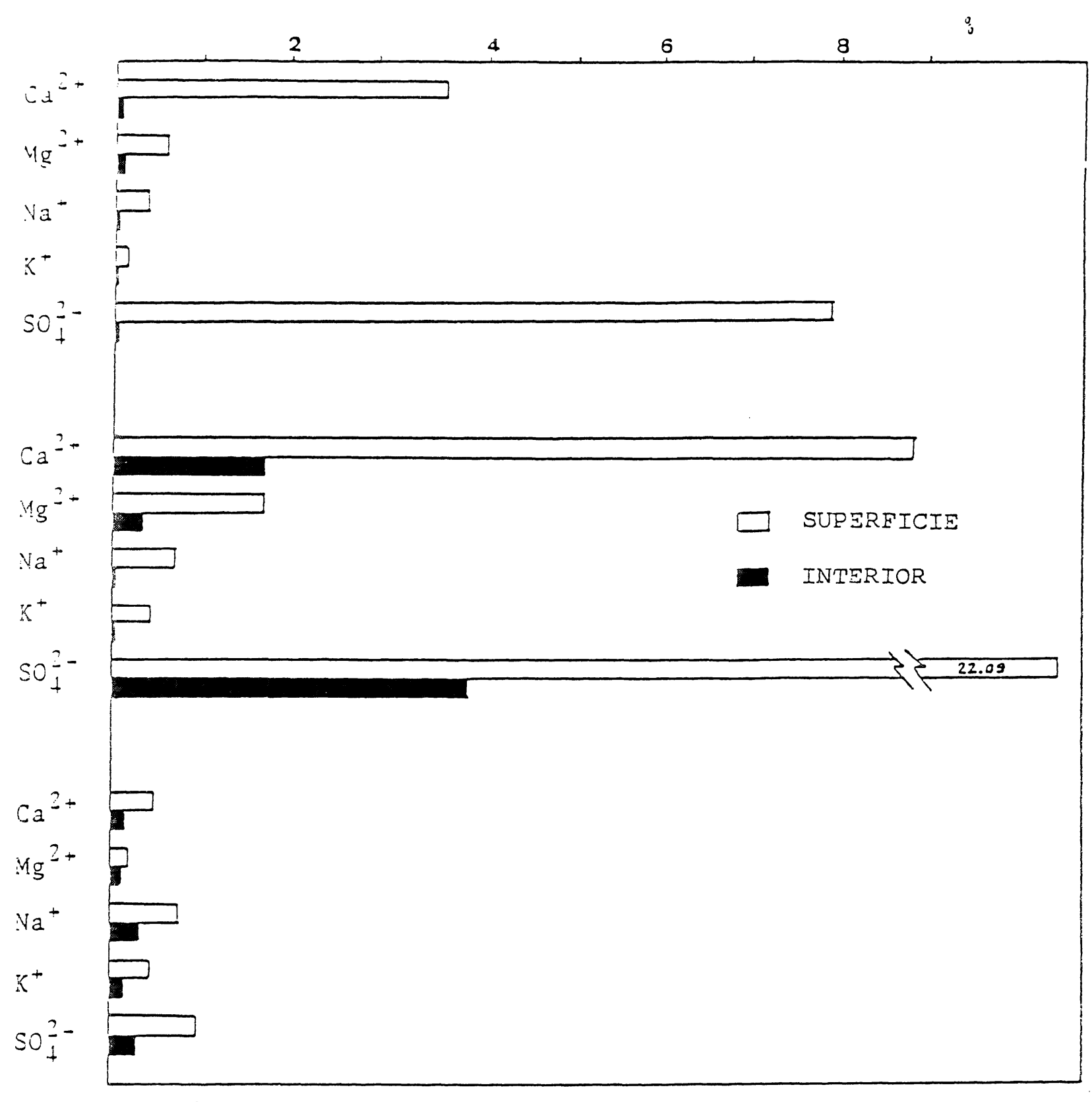

NOTA: $\mathrm{Mg}^{2+}(\mathrm{x} 100), \mathrm{Na}^{+}$y $\mathrm{K}^{+}(\mathrm{x} 10)$

Fig. 6. - Contenido (\%) de diferentes especies en la fracción sobluble en agua para varias muestras de la Catedral.

Fig. 6.-Contents (\%) of various ions in the water soluble fraction for samples from the Cathedral.

\subsection{Morfología microscóplca de alteración}

\subsubsection{Materiales del Puerto de Santa María}

Aun cuando estos materiales, como ya ha sido mencionado, presentan una gran variabilidad en su composición macroquímica, la morfología microscópica de la piedra sin alterar es prácticamente la

\subsection{Microscopic deterioration morphology}

4.4.1. Materials from Puerto de Santa María

Even when these materials, as has already been mentioned, present a great variation in their macrochemical composition, the microscopic morphology of the unaltered stones is practically the same for all of 
misma para todos: una matriz microcristalina de tipo calcítico con frecuentes inclusiones de macrocristales de calcio, Figura $7(a), y$, dependiendo del porcentaje de $\mathrm{SiO}_{2}$, de cristales de cuarzo, Figura 7(b).

Las muestras del edificio, alteradas fundamentalmente por el ataque del $\mathrm{SO}_{2}$ atmosférico, se encuentran "tapizadas", no sólo en la superficie, sino hasta profundidades incluso de unos centímetros, por cristales de yeso que ocupan el lugar de la primitiva matriz microcristalina, Figura 8(a), llegándose a formar con frecuencia estructuras cristalinas muy bien definidas de dicho compuesto, Figura $8(b)$.

\subsubsection{Materiales de Espera}

Aun cuando a simple vista parecen materiales muy heterogéneos, desde el punto de vista microscópico están formados

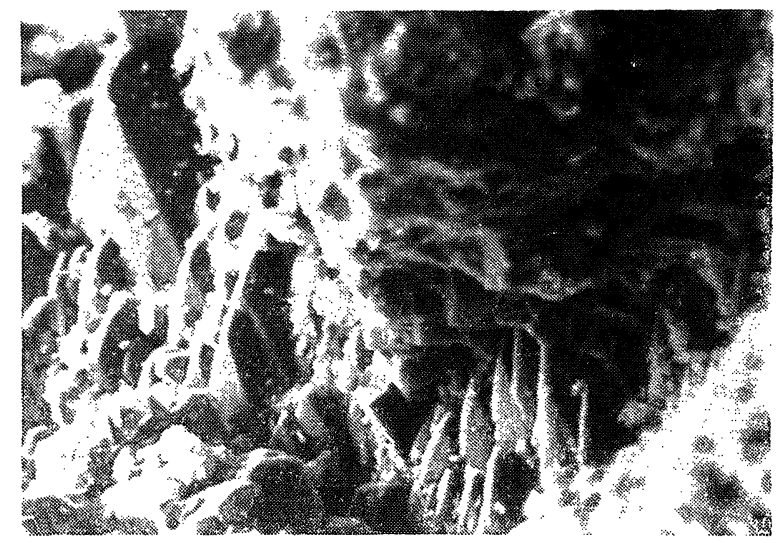

(a)

(b)

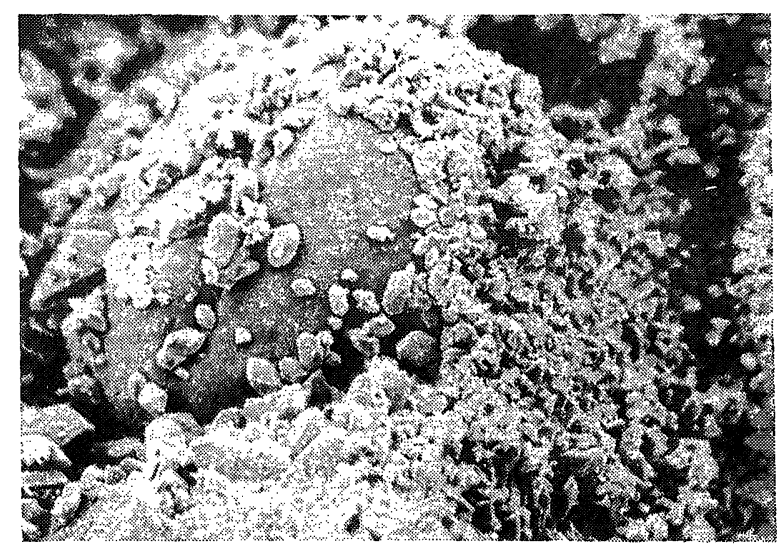

Fig. 7.-Microfotograflas de material inalterado procedente del PÜerto de Santa María. (a) X400; (b) ×190.

Fig. 7.-SEM micrographs of non-deteriorated stone from Puerto do Santa Marla. (a) X400; (b) $\times 190$ them, a microscrystalline matrix of calcite type with frequent encasements of calcite crystals, Figure 7(a), and, depending of the $\mathrm{SiO}_{2}$ percentage, quartz crystals, Figure 7(b).

The samples from the building, basically deteriorated by the $\mathrm{SO}_{2}$ attack, are found "draping" not only on the surface but even at depths of a few centimetres by gypsum crystals which occupy the place of primitive microcrystalline matrix, Figure 8(a), frequently forming very well-defined crystalline structures, Figure $8(b)$.

\subsubsection{Materials from Espera}

Even though at first sight they seem heterogeneous materials, microscopically they are almost totally formed by small and

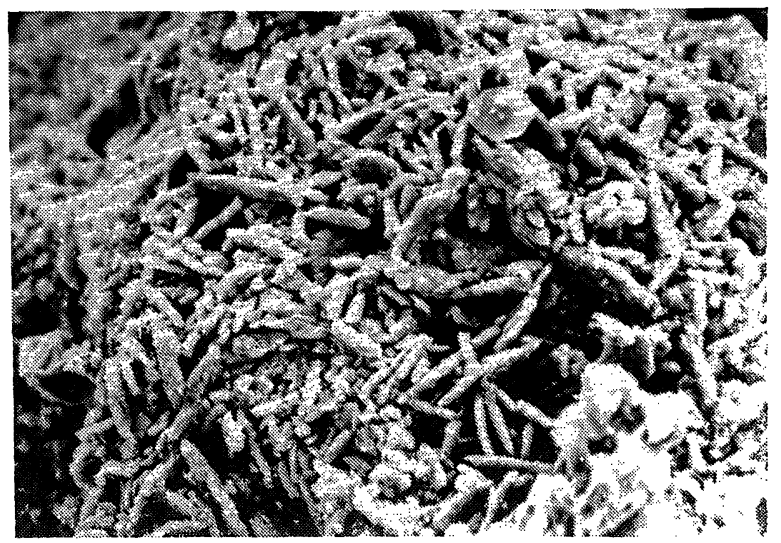

(a)

(b)

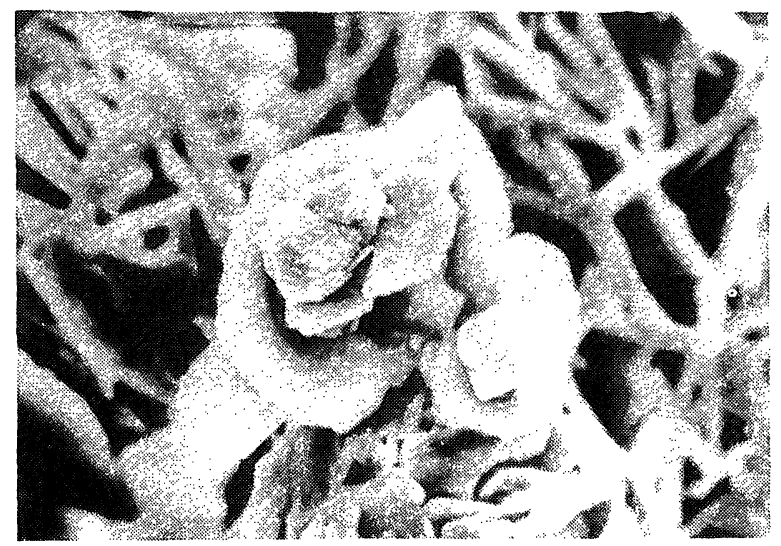

Fig. 8.-Microfotograflas de material alterado del edíicicio procedente del Puerto de Santa Marla. (a) x750; (b) x2.000.

Fig. 8.-SEM micrographs of deteriorated building stone from Puerto do Santa Marla. (a) $\times 750$; (b) $\times 2.000$. 
casi totalmente por pequeños cristales de calcita formas redondeadas, Figura 9(a), siendo relativamente frecuente el que se produzcan recristalizaciones calcíticas bien definidas, Figura 9(b), en el interior de los poros.

En el material alterado tomado en la Catedral cabe destacar que la estructura original se conserva pero con formas algo round calcite crystals, Figure 9(a), being relatively frequent well-defined calcitic recrystallizations in the interior of the pores, Figure 9(b).

In the deteriorated material taken from the Cathedral we would emphasize that the original structure is conserved but with
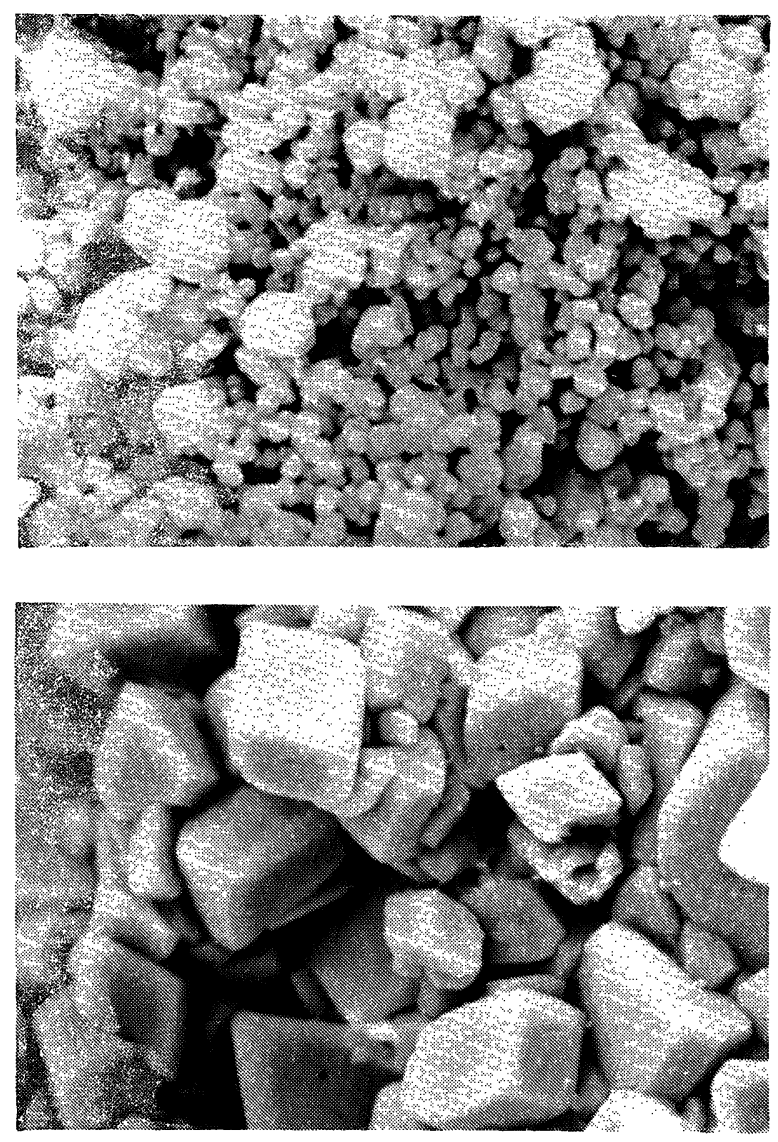

más suavizadas. Estos materiales, al igual que los del Puerto de Santa María, sufren una fuerte alteración por el $\mathrm{SO}_{2}$ atmosférico apareciendo cristalizaciones bien definidas de yeso, Figura 10 , aunque de menor tamaño que en aquellos y solo en una fina capa superficial; por debajo, la cristalización es amorfa y deslocalizada. Este hecho puede tener su explicación en la diferente porometría de ambos materiales; como se puede apreciar en la Figura 11, en los materiales de Espera abundan los microporos, por lo que los cristales ven dificultado su crecimiento en el interior de la piedra a diferencia de lo que ocurre en los materiales del Puerto de Santa Marla, donde abundan los macroporos.
Fig. 9.-Microiotografías de material inalterado procedente de Espera. (a) $\times 3.300$; (b) $\times 1.900$.

Fig. 9.-SEM micrographs of non-deteriorated stone from Espera (a) $\times 3.300$; (b) $\times 1.900$.

(a)

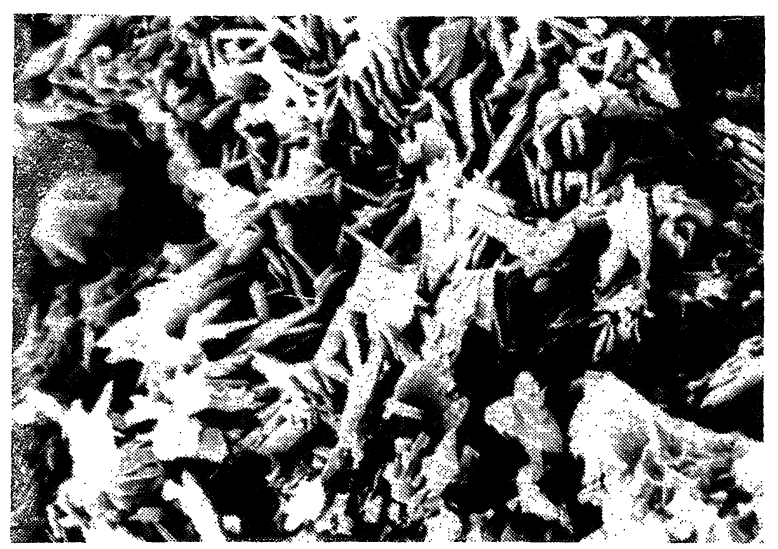

Fig. 10.-Microfotografla de material de Espara alterado (x4.000).

(b) Fig. 10.-SEM micrograph of deteriorated building stone from Espera ( 44.000$)$.

softer forms. These materials like those from Puerto de Santa María, undergo a strong deterioration by $\mathrm{SO}_{2}$ with formation of well-defined crystallizations of gypsum, Figure 10, although lesser in size that those of Puerto de Santa Maria and only in a fine superficial layer; underneath the crystallization is amorphous and hidden. This fact can be explained by the different pore size distribution in both materials; as can be seen in Figure 11, micropores abound in the materials from Espera, which means their growth is made difficult in the interior of the stone which is exactly the opposite to what happens to the stones from Puerto de Santa Maria, where the macropores abound. 


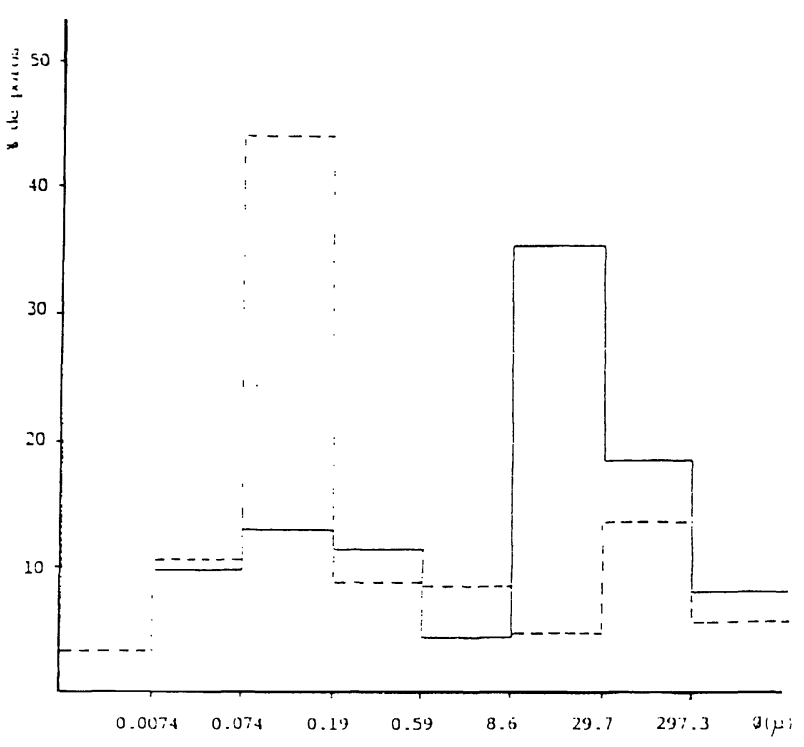

\subsubsection{Materiales de Monóvar}

En la Figura 12 se observa el aspecto general de estos materiales, formados por oolitos así como por grandes cristales de calcita homogeneamente repartidos; ambos se encuentran bien cementados por una matriz microcristalina de tipo calcítico.

En cuanto al material alterado, en la Figura 13(a) se puede observar la notable pérdida de matriz que se produce,

Fig. 12.-Microfotografía de material alterado procedente de Monóvar (x22).

Fig. 12.-SEM micrograph of non-deteriorated building stone from Monóvar (x22).

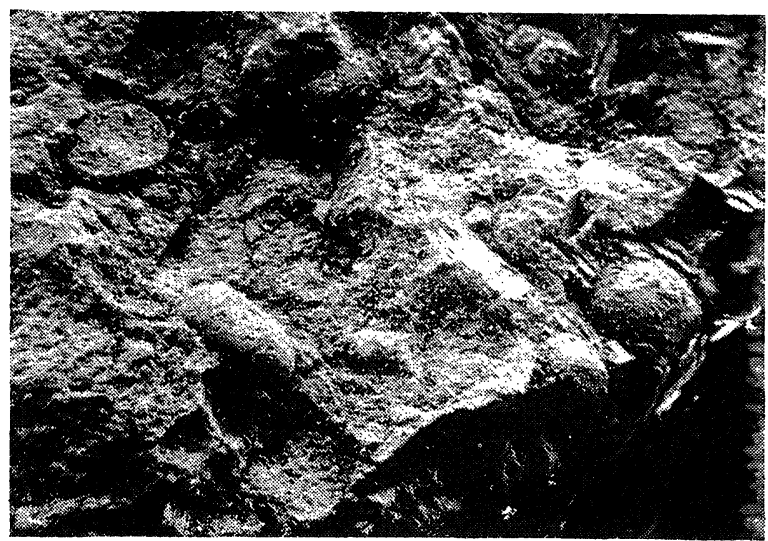

Fig. 13.- Microfotografías de material alterado procedente de Monóvar. (a) $\times 17$; (b) $\times 190$.

Fig. 13.-SEM micrograph of non-deteriorated material from Monóvar. (a) x17; (b) x190.
Fig. 11.-Distribución "media" de diámetro de poro en los materiales de Espera (--) y del Puerto de Santa Marla. (-).

Fig. 11.-Pore size distribution "type" in the materials from Espera (--) and Puerto do Santa Marla (-).

\subsubsection{Materials from Monóvar}

In Figure 12 we observe the genera! appearance of these materials, formed by oolites as well as large crystals of calcite homogeneously dispersed; both are well cemented by a microcrystalline matrix of calcitic type.

In respect to the deteriorated material, in Figure 13(a) we can see the notable loss of matrix produced, leaving the oolites

(a)

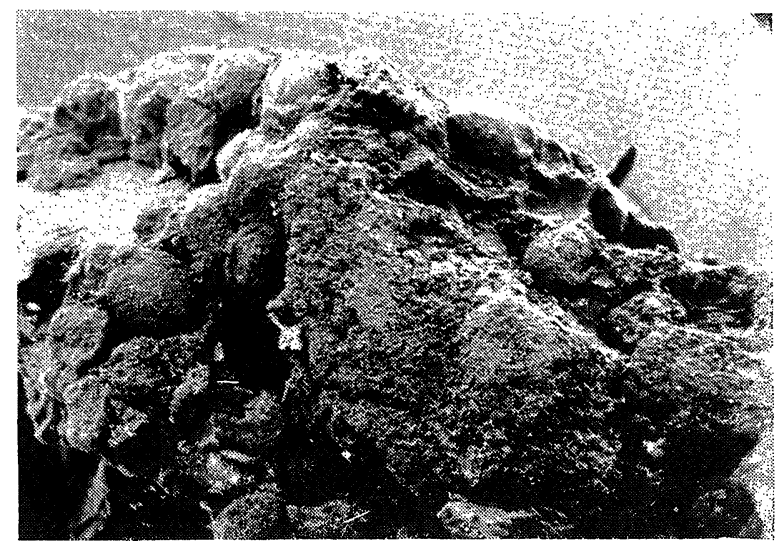

(b)

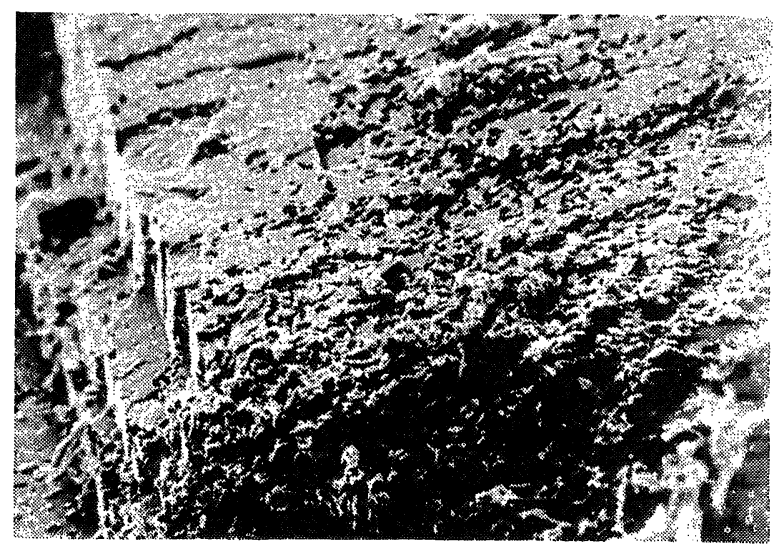


quedando así "sueltos" los oolitos. Las macroestructuras calcíticas sufren un proceso de disgregación, Figura 13(b), que comienza por un "picado". Por similitud con oiros estudios realizados por los autores, éste último proceso podría tener su origen en "choques térmicos" puesto que durante el verano pueden alcanzarse durante el día temperaturas próximas a los $60^{\circ} \mathrm{C}$ en la superficie de la piedra.

C) hecho de que no se aprecien formaciones de yeso puede deberse al acabado "fino" que presentan estos materiales en el edificio ya que son relativamente nuevos (finales del s. XIX, comienzos del $s$. $X X)$, por lo que se han visto poco alterados por agentes naturales; el dióxido de azufre parece atacar preferentemente la matriz microcristalina cero en una capa muy superficial, por lo que el yeso formado puede ser "barrido" fácilmente por el agua de lluvia.

\subsubsection{Materiales de Utrera}

Microscópicamente son materiales de aspecto muy heterogéneo con importantes procesos de recristalización calcítica secundaria, Figura 14.

En cuanto al material alterado, cabe destacar la formación de macroporos, Figura 15, debidos posiblemente a fenómenos de disolución-recristalización ya que se localizan en las zonas bajas de la fachada sur, con fuerte insolación $y$ "free". The calcitic macrostructures undergo a process of disagregation, Figure 13(b), which starts with a "pitting". For similarity with other studies carried out by the author, this last process could have its origin in thermal variations since, during Summer, temperatures around $60^{\circ} \mathrm{C}$ can be reached on the surface of the stone.

The fact of not being able to see gypsum formations could be due to the "smooth" finishing which these materials present in the building as they are relatively new (end of nineteenth century, beginning of the (wentieth) so that they have not been very deteriorated by natural agents. The sulphur dioxide seems preferably to attack the macrocrystailine matrix but on a very superficial layer so the gypsum formad can be "brushed away" by rainwater.

\subsubsection{Materials from Utrera}

Microscopically they are materials of a very heterogeneous appearance with important secondary calcitic recrystallization processes, Figure 14.

In respect to the deteriorated material, we emphasize the formation of macropores, Figure 15, due to disolution-recrystallization phenomena which are located on the lower areas of the southern facade, with strong insolation and capillary ascension of water.

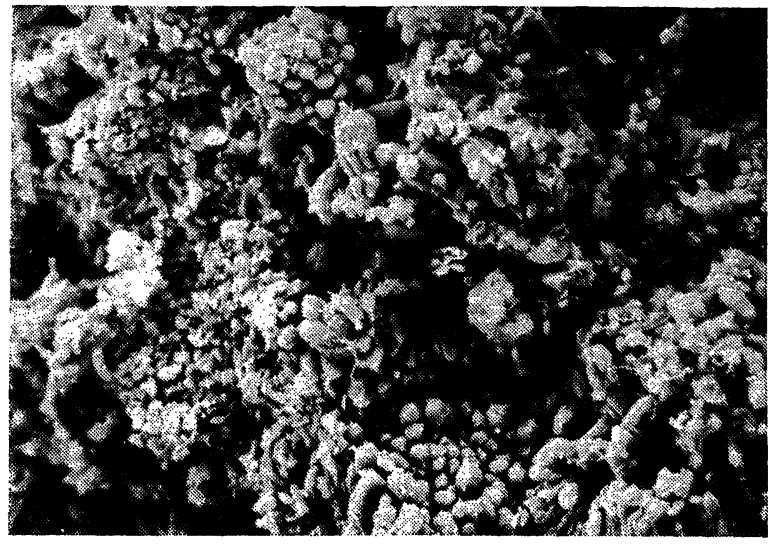

Fig. 14.- Microfotografla de material inalterado procedente de Utrera $(x 880)$.

Fig. 14. - SEM micrograph of non-deteriorated stone from Utrera (x880).

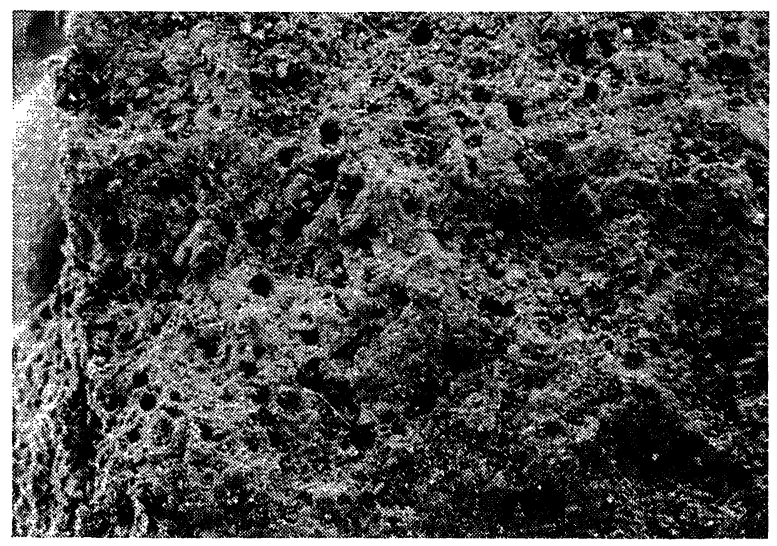

Fig. 15.-Microfolografla de material alterado procedente de Utrera (x41)

Fig. 15. - SEM micrograph of deteriorated building stone from Utrera (x41). 
ascensión capilar de agua del subsuelo. Aparecen también frecuentes grietas $y$, debido a la alta humedad a que se encuentra sometida la piedra, se da una extraordinaria proliferación de hongos.

\subsubsection{Materiales de Morón}

El aspecto general de los materiales de esta procedencia es el que se aprecia en la Figura 16, estructura relativamente homogénea en la que se halla muy extendido el fenómeno de recristalización.

El ataque producido por el $\mathrm{SO}_{2}$ sobre los materiales del edificio se manifiesta con la formación de cristales de yeso,

generalmente muy aislados, Figura 17. Debido a que estos materiales, al igual que los de Utrera, se encuentran en zonas bajas del edificio, el ascenso capilar de agua del subsuelo ha provocado el redondeamiento de las estructuras primitivas.

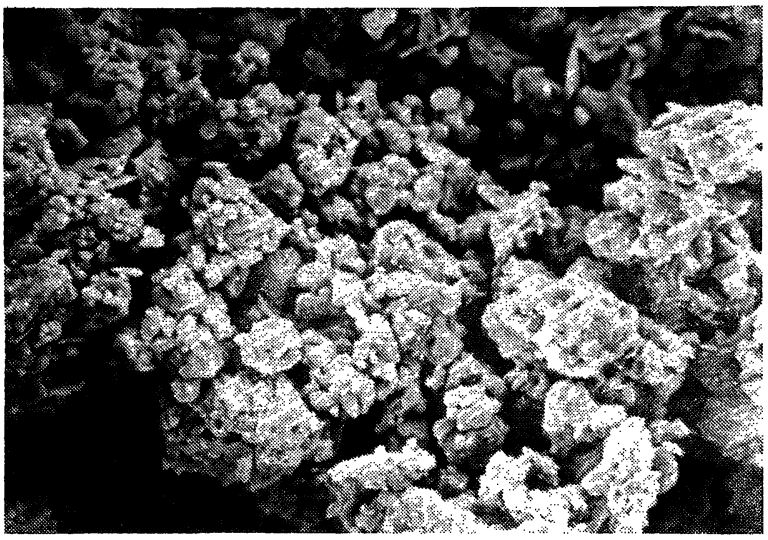

Fig. 16.-Microfotografía de material inalterado procedente de Morón (x160).

Fig. 16.-SEM micrograph of non-deteriorated building stone from Morón (x160).

\subsection{Experiencias del alteración acelerada}

A fin de establecer los mecanismos de alteración por ataque con $\mathrm{SO}_{2}$, se han realizado experiencias de alteración acelerada, en las que muestras de canteras del Puerto de Santa María y Espera han sido sometidas, durante más de 700 horas, a una atmósfera de $1.000 \mathrm{ppm}$ de $\mathrm{SO}_{2}$, en condiciones de saturación de humedad y ciclos de humedad, manteniéndose constante la temperatura $\left(40^{\circ} \mathrm{C}\right)$.
Cracks also often appear and, due to the high humidity which the stone undergoes, there is an extraordinary fungi prolification.

\subsubsection{Materials from Morón}

The general appearance of materials from this place is that which is shown in figure 16, a relatively homogeneous structure in which recrystallization phenomena are widely found.

The $\mathrm{SO}_{2}$ attack on the building is shown by the formation of gypsum crystals, usually isolated, figure 17. As these materials, like those from Utrera, are found in the low areas of the building, the capillary ascension of water has provoked the rounding of the primitive structures.

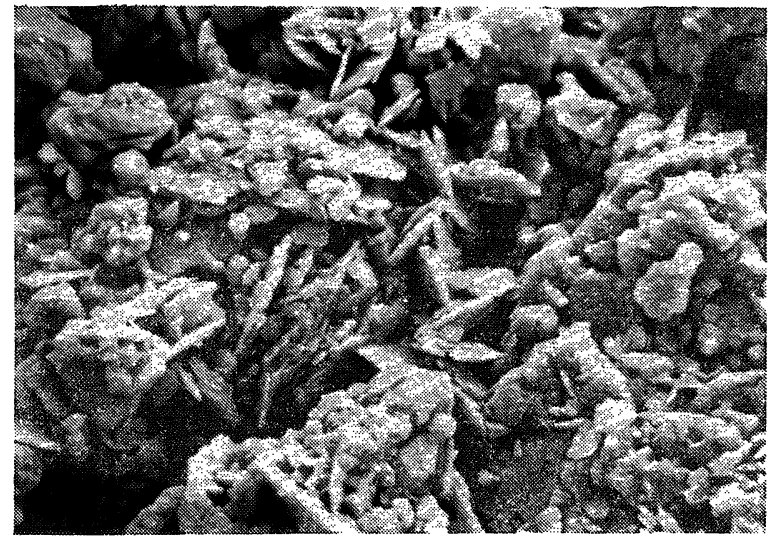

Fig. 17.-Microfotografla de material alterado procedente de Morón (x940).

Fig. 17.-SEM micrograph of deteriorated building stone from Morón (x940).

\subsection{Accelerated deterioration experiences}

For establish the deterioration mechanisms for the $\mathrm{SO}_{2}$ attack we have carried out accelerated deterioration experiences on the samples from the Puerto de Santa Maria and Espera quarries for more than 700 hours, at an atmosphere of $1.000 \mathrm{ppm}$ of $\mathrm{SO}_{2}$, in conditions of saturation of humidity and $40^{\circ} \mathrm{C}$. 
Por observación con microscopio óptico, se constata que la penetración del ataque es muy tenue y apenas alcanza los primeros $0.05 \mathrm{~mm}$, formándose una capa ligeramente más blanca.

Los difractogramas de rayos $X$ muestran la aparición de yeso, como principal producto, junto con algo de sulfito cálcico; se produce igualmente una reducción del contendido de calcita.

La similitud en la apariencia óptica y los datos de difracción de rayos $X$ correspondientes a condiciones de saturación de humedad y a ciclos de humedad contrasta con la apariencia observada con microscopio electrónico de barrido. La simulación de ciclos de humedad, incluyendo lluvia, da lugar a la disolución del sulfato cálcico formado en la capa más externa y el subsiguiente ataque a capas más interiores.

La morfología de las alteraciones observadas parece indicar que el ataque químico debe producir una disolución previa de la calcita que subsiguientemente da lugar a la cristalización y crecimiento de granos de yeso al evaporarse el agua de solución.

En la Figura 18 se pueden observar las alteraciones experimentadas en la piedra del Puerto de Santa María a nivel microscópico, en atmósfera de $\mathrm{SO}_{2}$ y
The observation by light microscopy show that the penetration of the attack is very feeble and hardly reaches the first 0.05 $\mathrm{mm}$, forming a slightly whiter layer.

The $X$-ray diffractograms show the apparition of gypsum, as the main product, together with some calcium sulphite; a reduction in the calcite content is also shown.

The similarity in the optic appearance and the $X$-ray diffractograms data corresponding to the saturation o humidity conditions and cycles of humidity contrast with the appearance observed by scanning electron microscopy. The simulation of humidity cycles, including rain, gives rise to the dissolution of calcium sulphate formed on the outer layer and the subsequent attack on the inner layers.

The morphology of the deterioration observed seens to indicate that the chemical attack must produce a previous dissolution of the calcite that subsequentially gives rise to the crystallization and growth of gypsum grains on upon the evaporation of the water solution.

In Figure 18 we can see the deterioration experimented in the stone from Puerto de Santa María at microscopic level, in $\mathrm{SO}_{2}$ atmosphere and humidity saturation

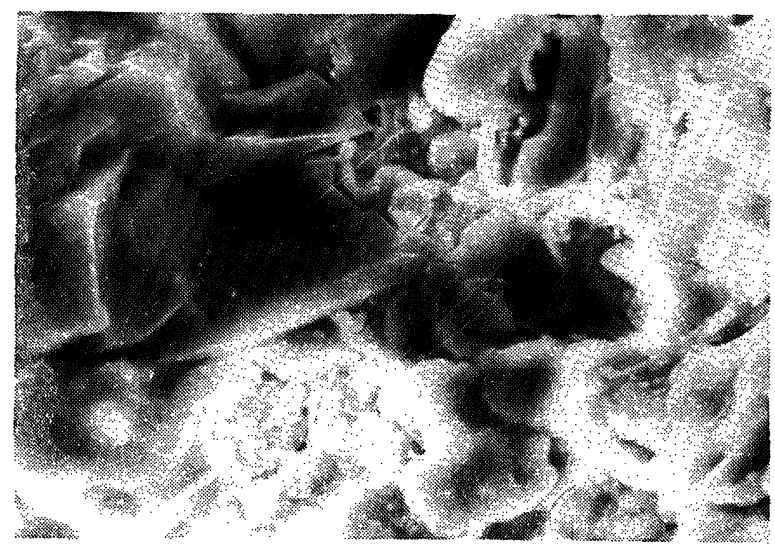

Fig. 18.-Microfotografla de material procedente del Puerto de Santa Marla sometido a experiencias de alteración acelerada (×2.000)

Fig.18. - SEM micrograph of stone from Puerto de Santa Marla before accelerated deterioration experiences (x2.000). 
condiciones de saturación de humedad. La superficie de la muestra aparece cubierta por una costra agrietada y con orificios, formada por $\mathrm{CaSO}_{4}$, según indica la microsonda de rayos $X$. En algunas zonas donde no aparece la costra se aprecian cristales de yeso no perfectamente formados unidos a la superficie.

La superficie de las muestras de Espera presenta un aspecto similar al de muestras inalteradas, se detecta la presencia de sulfato cálcico en cantidad apreciable y la formación de grietas.

La confluencia en muestras alteradas naturalmente de otros factores de alteración naturales, además de aquellos de acción química, podría justificar la apreciablemente diferente morfología microscópica de alteración observada en piedras sometidas a alteración al medio ambiente natural y aquellas alteradas en atmósferas controladas.

\section{CONCLUSIONES}

1) Los principales factores de alteración que determinan el preocupante estado de deterioro de la Catedral de Sevilla son de naturaleza antropogénica $y, a$ través de mecanismo de corrosión, determinan los dos tipos de indicadores de alteración más característicos en este edificio: las costras y los depósitos superficiales.

2) La variación de la composición macroquímica se debe, en la Catedral de Sevilla, a un notable incremento de la concentración de sulfatos, que puede pasar de un valor de alrededor al $0.5 \%$ de $\mathrm{SO}_{3}$ (zona interna del material, no alterada) hasta valores del $42 \%$ (aproximadamente $71.5 \%$ de $\mathrm{CaSO}_{4}$ ) en las partes más alteradas.

3) Mediante el estudio por difracción de rayos $X$ se ha podido comprobar que el ataque por $\mathrm{SO}_{2}$, previa oxidación a $\mathrm{SO}_{3}$, sobre las piedras calizas provoca la transformación de la calcita en yeso.

4) Como consecuencia de procesos de corrosión se produce un notable enriquecimiento en elementos traza, puesto de relieve en su composición microquímica. Existe una estrecha relación entre dicho enriquecimiento en elementos traza y los depósitos conditions. The surface of the sample is covered by a cracked crust with holes formed by $\mathrm{CaSO}_{4}$, according to microprobe data. In some areas where the crusting does not appear, there are gypsum crystals, not yet perfectly formed, joined to the surface.

The surface of the Espera samples shown a similar appearance to unaltered stone and there are a great amount of $\mathrm{CaSO}_{4}$ and cracks.

The yuxtaposition of other natural factors on the building stones, besides those of chemical action, could justify the appreciably different microscopic morphology of deterioration observed in stones that have undergone deterioration in the natural environment to those deteriorated in accelerated conditions.

\section{CONCLUSIONS}

1) The main factors of deterioration which determine the worrying state of the Cathedral of Sevilla are anthropogenic origin and, by corrosion mechanisms determine the two types of indicators of deterioration most characteristics in this building: crusting and superficial deposits.

2) The variation in the macrochemical composition in the Cathedral of Seville is due to a notable increase in the concentration of sulphates, which can range from a value of around $0.5 \%$ of $\mathrm{SO}_{3}$ (internal area of material unaltered) to $42 \%$ (approximately $71,5 \%$ of $\mathrm{CaSO}_{4}$ ) in the most deteriorated stones.

3) By $X$-ray diffraction studies we have been able to check that the $\mathrm{SO}_{2}$ attack on the limestones provokes a transformation of calcite into gypsum.

4) As a consequence of corrosion processes, a remarkable enrichment in trace elements is produced, outstanding in its microchemical composition. A close relationship between the enrichment in trace elements and the superficial deposits, and between these and the 
superficiales y entre éstos y el tráfico rodado. La presencia de algunos de esos elementos justifica la oxidación catalítica del $\mathrm{SO}_{2}$ a $\mathrm{SO}_{3}$.

5) Existe una evidente correlación entre el grado de alteración de los materiales pétreos, la concentración de plomo y la ubicación de los mismos en el edificio.

6) La concentración de sales solubles en los materiales pétreos alterados guarda también una evidente relación con los citados procesos de alteración química, y están constituidas esencialmente por sulfatos. Los valores de conductividad (salinidad total) oscilan entre $45 \mu \mathrm{s} / \mathrm{cm}$ para las zonas no alteradas hasta $800 \mu \mathrm{s} / \mathrm{cm}$ para las partes más alteradas de los mismos.

7) La morfología microscópica de alteración por $\mathrm{SO}_{2}$ es característica de cada litotipo.

8) Se ha reproducido en el laboratorio el mecanismo de alteración por ataque con $\mathrm{SO}_{2}$ mediante experiencias de alteración acelerada, poniéndose en evidencia la acción concomitante de otros factores de alteración naturales.

\section{AGRADECIMIENTO}

Los autores desean expresar su agradecimiento al Dr. Eduardo Mayoral Alfaro del Departamento de Geología y Minería de la Universidad de Sevilla por su colaboración en los datos mineralógicos-petrográficos. traffic is found. The presence of some of these elements justifies the catalitic oxidation of $\mathrm{SO}_{2}$.

5) An evident correlation exists between the degree of deterioration of petreous materials, its lead cocentration and their location in the building.

6) The concentration of soluble salts in the deteriorated stones also has an evident relationship with the cited processes of chemical deterioration, and they are constituted essentially by sulphates. The values of conductivity (total salinity) oscillate between $45 \mu \mathrm{S} / \mathrm{cm}$ in the non-deteriorated stones to $800 \mu \mathrm{S} / \mathrm{cm}$ in the most deteriorated ones.

7) The microscopic morphology of deterioration by $\mathrm{SO}_{2}$ is characteristic for each lithotype.

8) The mechanism of deterioration by $\mathrm{SO}_{2}$ attack has been reproduced in the laboratory by means of experiences of accelerated deterioration, discovering the concomitant action of other natural factors of deterioration.

\section{ACKNOWLEDGEMENTS}

We appreciate greatly the collaboration of Dr. Eduardo Mayoral Alfaro (Departamento de Geología y Minería, Universidad de Sevilla) for the mineralogical-petropraphic data.

\section{REFERENCIAS \\ (REFERENCES)}

(1) "Guia resumida del clima de España", INM, Madrid, 1983.

(2) "Climatología de España y Portugal", INM, Madrid, 1983.

(३) "Atlas climático de España", INM, Madrid, 1983.

(4) Datos proporcionados por el Centro Meteorológico Zonal de Sevilla.

(5) PEREZ DE LEON, B.; CORTES, V.: "Emisiones e inmisiones de $\mathrm{SO}_{2}$ y humos en Sevilla. Fenomenologia e interrelaciones", Publ. Univ. de Sevilla, número 2, 1986.

(6) USERO, J. et al "Estudio de la contaminación atmosférica de la Ciudad de Sevilla por partículas sedementables: 1. Fracción soluble", Ingenieria Química, 176, 1983, 149-153. 
(7) USERO, J. et al "Estudio de la contaminación atmosférica de la Ciudad de Sevilla por partículas sedimentables: II. Fracción insoluble", Ingenieria Química, 177, 1983, 113-116.

(8) MELGAREJO, P. et al "A study of the atmospheric lead pollution in Sevilla, Spain. Influence of meteorology and traffic and relationship with other traffic-generated pollutants", Int. J. of Environmental Analytical Chemistry, 24, 1986, 283.

(9) BELLO, M.A.; MARTIN, A.: "Microchemical characterization of stones used in historic building. Interpretation of analytical information by Pattern Recognition methods", Archacometry, pendiente.

(10) ALCALDE, M.: "Tesis Doctoral", Sevilla, 1989.

(11) JIMENEZ, J.; JUSTO, J.: "Geotécnia y cimientos: propiedades de los suelos y las rocas", Ed. Rueda, Madrid, 1971.

(12) WALLACE, K.: "Structural behaviour of residual soil of the continually wet Highlands of Papua New Guinea", Geotechnique, 23 (2), 1973, 203-218.

(13) NASCIMENTO, U. et al "Identification of petrification in soils", Proc. 6th Int. Conf. on Soils Mechanics and Foundation Engineering, Toronto, 1965, 80-82.

(14) ARNAIZ, M.; MARTIN, A.: "Alteración de materiales pétreos de obras monumentales. Acción de la contaminación ambiental", Monografía del Inst. Eduardo Torroja (CSIC), n. 340, 1977.

(15) USERO, J. et al: "A determination of the sources in the Seville urban aerosol", Inter. J. Environ, Anal. Chem. (pendiente).

(16) NORMAL (CNR/ICR) 13/83 "Dosaggio dei sali solubili".

\section{publicación del ICCET/CSIC}

\section{INSPECCION DE OBRAS DAÑADAS POR CORROSION DE ARMADURAS}

El presente Manual va dirigido principalmente a técnicos especializados y laboratorios que tienen que intervenir en el dictamen de la situación de deterioro de estructuras de hormigón armado dañadas por corrosión de armaduras.

Comienza con un resumen recordatorio de los factores principales a los que se pueden deber los daños prematuros por corrosión de armaduras, para seguir con algunas indicaciones de cómo se deben realizar las inspecciones, y de los ensayos y la metodología que se recomienda realizar para poder dictaminar con precisión las causas de daño.

A continuación se hacen una serie de comentarios sobre la vida residual de estructuras dañadas, sobre el riesgo de corrosión futura, el seguimiento necesario de una estructura reparada y una breve enumeración de métodos de reparación y consideraciones básicas a tener en cuenta en la recomendación de un determinado método. Se aporta una breve relación bibliográfica.

Finalmente se incluyen en forma de ficha la descripción de algunos casos de corrosión de armaduras detectados en nuestro país.

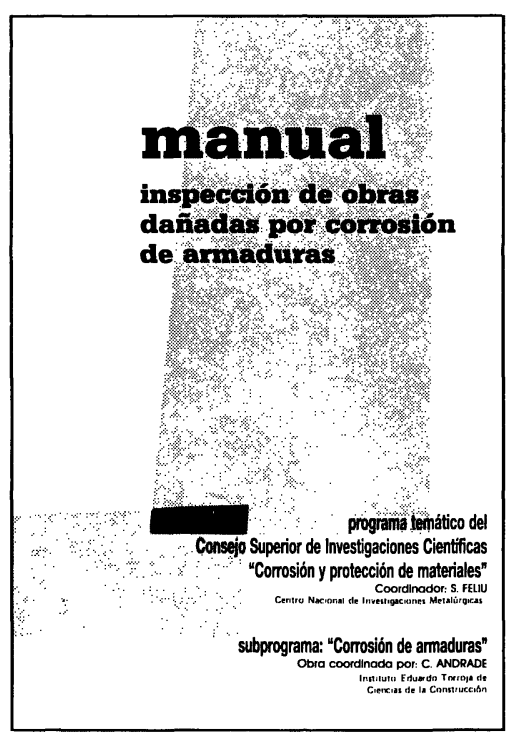

